Original Article

Artigo Original

Natália Barreto Frederigue-Lopes ${ }^{1}$ Maria Cecilia Bevilacqua ${ }^{1,2}$ Orozimbo Alves Costa ${ }^{1}$

Keywords

Cochlear Implantation

Adult

Music

Questionnaires

Hearing Loss

Descritores

Implante Coclear

Adulto

Música

Questionários

Perda Auditiva
Correspondence address:

Natália Barreto Frederigue Lopes Departamento de Fonoaudiologia, Faculdade de Odontologia de Bauru, Universidade de São Paulo Alameda Octávio Pinheiro Brizola, 9-75, Bauru (SP), Brasil, CEP: 17012-901.

E-mail: natalia@frederigue.com.br

Received: 04/14/2014

Accepted: 12/27/2014

\section{Munich Music Questionnaire: adaptation into Brazilian Portuguese and application in cochlear implant users}

\author{
Munich Music Questionnaire: adaptação para a língua \\ portuguesa e aplicação em usuários de implante coclear
}

\begin{abstract}
Purpose: To translate the Munich Music Questionnaire (MUMU) to Brazilian Portuguese, to adapt it culturally, and to describe the results obtained among adult users of cochlear implant (CI). Methods: We translated the questionnaire to Brazilian Portuguese, reviewed the grammatical and idiomatic equivalences (back-translation), and adapted it from a linguistic and cultural perspective. The resulting version of this process was applied among adult CI users through direct interviews. Results: The Brazilian Portuguese version of MUMU was applied to 19 adult CI users with postlingual hearing loss, who had been users of the device for at least one year. The answers to the questionnaire were analyzed by distribution of frequency and percentage of occurrence in each question. The results showed a decrease in the frequency of CI users that listen to music, comparing the period before hearing loss and after the CI. Regarding the role that music played in the life of each participant, the responses did not score change, so the music remained being an important factor in the life of the evaluated subjects, even after the CI. Conclusion: The subjective evaluation tool MUMU was translated and culturally adapted to the population studied. In Brazilian Portuguese, it was called Questionário de Música de Munique. The study showed its applicability in the daily monitoring of CI users, thus providing a profile of the activities related to music in everyday life.
\end{abstract}

\section{RESUMO}

Objetivos: Traduzir e adaptar, culturalmente, para a língua portuguesa o questionário Munich Music Questionnaire (MUMU) e descrever os resultados obtidos em adultos usuários de implante coclear (IC). Métodos: Foi realizada tradução do questionário para a língua portuguesa, revisão das equivalências gramatical e idiomática (traduções reversas) e adaptação linguística e cultural. A versão resultante desse processo foi aplicada em adultos usuários de IC por meio de entrevista dirigida. Resultados: Com a obtenção do Questionário de Música de Munique na língua portuguesa, o mesmo foi aplicado em 19 adultos usuários de IC com deficiência auditiva adquirida no período pós-lingual, com um tempo mínimo de uso de um ano do dispositivo. As respostas do questionário foram analisadas pela distribuição da frequência e porcentagem de ocorrência em cada questão. Os resultados evidenciaram uma diminuição na frequência com que os implantados ouviam música ao comparar o período anterior à perda auditiva e após o IC. Quanto ao papel que a música desempenhou na vida de cada participante, as repostas não pontuaram mudança, de forma que a música continuou sendo importante na vida dos sujeitos avaliados, mesmo após o IC. Conclusão: O instrumento de avaliação subjetiva MUMU foi traduzido e adaptado, culturalmente, para a população estudada. Em língua portuguesa, sua denominação foi Questionário de Música de Munique. O estudo permitiu verificar a sua aplicabilidade na rotina clínica de acompanhamento de usuários de IC, estabelecendo, assim, um perfil das atividades ligadas à música no dia a dia.

Study carried out at the Center of Audiological Research, Hospital of Rehabilitation of Craniofacial Anomalies, Universidade de São Paulo - USP - Bauru (SP), Brazil.

(1) Speech Language Pathology and Audiology Department, Dental School of Bauru, Universidade de São Paulo - USP - Bauru (SP), Brazil.

(2) Center of Audiological Research, Hospital of Rehabilitation of Craniofacial Anomalies, Universidade de São Paulo - USP - Bauru (SP), Brazil.

Financial support: Fundação de Amparo à Pesquisa de São Paulo - FAPESP - process n. 2007/59972-0.

Conflict of interests: nothing to declare. 


\section{INTRODUCTION}

Music plays an important role in people's lives and has the potential to restore and maintain mental health. Music is entertainment, fun, and relaxation ${ }^{(1)}$. Cochlear implant (CI) users describe music as being an important matter to be considered after the improvement in the perception of speech sounds ${ }^{(2)}$.

Studies conducted in the 1990s already mentioned that CI users longed for pleasant music perception ${ }^{(3)}$. Others showed that less than one-third patients could perceive music with the $\mathrm{CI}^{(4,5)}$. The impact of music on the quality of life of CI users was investigated, and the authors observed that the levels of music appreciation were significantly lower after surgery when compared to the period before hearing loss (HL). Besides, the time dedicated to listening to music in a week was significantly lower after the $\mathrm{CI}^{(5)}$.

Generally, CI users judge music perception as unsatisfactory, and no longer participate in musical activities because of that ${ }^{(6)}$.

Studies indicate the need to use subjective measures that can specify the real impression of music perception by CI users ${ }^{(7-10)}$.

This has been a common scientific practice, however, most instruments of subjective measure related to music perception in implant users are available in English.

In Brazil, these materials are lacking in the field of Speech Language Pathology and Audiology; therefore, one strategy to solve this problem is the translation of instruments that are already available in other languages ${ }^{(11)}$.

The Munich Music Questionnaire (MUMU) was especially created for the adult population with postlingual HL who were $\mathrm{CI}$ users. This questionnaire includes sections approaching the past and the present of the activities related to the habit of listening to $\mathrm{music}^{(8)}$.

MUMU was already translated and adapted to French, Spanish, and German. The questionnaire has been used as an additional measure in objective music perception and speech recognition tests; therefore, it is a complementary and necessary instrument to assess the aspects of music appreciation among adult $\mathrm{CI}$ users with postlingual $\mathrm{HL}^{(9-12)}$.

A recent study used MUMU to pair the music experience and the motivation to listen to music among 12 adults with postlingual HL who were users of $\mathrm{CI}$ and 12 adults with normal hearing. Another measure used by the authors was the emotion classification test for music sounds (Mu.S.I.C. Test). In this test, individuals were asked to listen to parts of a song and choose whether that part reflected happiness or sadness. A 1- to 10-point scale was used: 1 represented a very sad feeling, and 10, a very happy one. The results showed that the group of CI users presented a similar mean score in terms of emotion of the song when compared to the group of normal hearing participants; however, CI users reduced their auditory experience to music after the use of $\mathrm{CI}$ because they were found to be less motivated to take part in activities involving music when compared to the period before $\mathrm{HL}^{(13)}$.

The following were the objectives of this study:

- To culturally adapt MUMU to Portuguese;

- To describe the obtained results by applying this questionnaire to adult CI users.

\section{METHODS}

This study was conducted at the Center of Audiological Research, from the Hospital of Rehabilitation of Craniofacial Anomalies (HRAC), at Universidade de São Paulo (USP). The approval from the Human Research Ethics Committee at HRAC was obtained by protocol n. 309/2007-SVAPEPE-CEP. All participants signed the informed consent.

The adult CI users with postlingual $\mathrm{HL}$, who had been using the device for at least one year were included in the study.

\section{Instruments and procedures}

MUMU contains 25 questions to register the music listening habits in relation to the several music styles, different instruments, places to listen to music in, use of auxiliary equipment, and the participation in musical activities in the different moments of the lives of CI users.

The instrument offers many options of responses, ranging from the format yes $(\mathrm{Y})$ or no $(\mathrm{N})$ to scales of classification and multiple-choice questions with the possibility of marking as many options as necessary.

Questions 1, 2, 3, 14, 15, 19, and 20 approach three occasions: before HL, after HL before using a CI, and after the CI surgery. Questions 17 and 18 involve, in addition to the three periods, the time when the user was a child.

The translation and cultural adaptation of MUMU was in accordance with the methodology indicated by Guillemin et al. ${ }^{(14)}$, which included the translation from English to Portuguese and language adaptation, grammatical and idiomatic equivalences, and cultural adaptation.

\section{Translation from English}

\section{to Portuguese and language adaptation}

The original version of MUMU, in English, was given to three translators-interpreters who were fluent in that language. They did not know each other and were not previously familiar with the questionnaire. The objective was to elaborate three independent versions of MUMU in Portuguese, individually and confidentially.

Afterwards, the revision group was formed and comprised two Brazilian speech language pathologists who were fluent in English. The group was in charge of analyzing the three documents resulting from the first translations and, in consensus, reducing the differences found by choosing the best expressions and words in all of the questions, thus adapting the text to the Brazilian cultural knowledge.

Therefore, a new and single questionnaire was obtained and called Questionário de Música de Munique.

\section{Revision of grammatical and idiomatic equivalence}

This stage consisted of the back-translation. The Questionário de Música de Munique was sent to three other translators, whose language and cultural condition was similar to that of the former. These translators were not familiar with the original text 
and did a new version in English. These new translators were not allowed to see the original text, written in English, to prevent any influence on the translation. The same revision group again assessed the three versions and compared them to the original in English.

\section{Cultural adaptation}

Cultural adaptation aimed at establishing the cultural equivalence between the versions in English and in Portuguese of the questionnaire. According to Guillemin et al. ${ }^{(14)}$, cultural equivalence is established when there are no difficulties to understand the elaborated questions or the words used by the assessed population, when at least $80 \%$ individuals can answer each question easily. In case this number exceeds the established limit, this question is individually submitted to a new process of translation and version.

The questionnaire was always applied by the same researcher, who read out each question loud. All participants were interviewed individually.

\section{Data analysis}

For data analysis and data presentation, questions 1, 2, 3, 7, 14 , and 15 were chosen to be described for this studied group, which involved different aspects of music perception in the routine of the analyzed population, because the questionnaire offers several questions and answers.

Questions 1, 2, and 3 presented only one choice of response for selection. In this case, tables with frequencies and percentages were built in the obtained response. For questions 7 , 14 and 15 , the participant could mark more than one answer.
In the analysis of these questions, tables with the distribution of frequencies and percentages of each category of response were built.

For questions 1 and 2, the measured attitudes were analyzed by using the 5-point Likert scale. The following classification was applied:

Q1: 1=never, 2=rarely, 3=occasionally, 4=frequently, and $5=$ always.

Q2: 1=none, 2=little, 3=medium, 4=important, and 5=very important.

Descriptive statistics was used to characterize the sample.

\section{RESULTS}

On the basis of the established criteria, 19 adults took part in this study. They were cared for during the follow-up routine in the CI service from November 2009 to February 2010. The mean age of participants was 44 years old (ranged from 22 to 63 years), being 14 male and 5 female individuals. The individual information of the participants is presented in Table 1.

In the stage of cultural equivalence, no difficulties were observed to understand the questions, so it was not necessary to reformulate them.

The Questionário de Música de Munique (Portuguese version) is exposed in Appendix 1.

For matters characterizing musical activities in different periods of the user's life, the presentation of results only showed moments before HL and after the CI because the period after HL and before surgery showed absence of activities related to music, for the studied population, due to auditory deprivation.

Table 1. Individual characteristics and demographic data of all assessed participants $(n=19)$

\begin{tabular}{|c|c|c|c|c|c|c|}
\hline Participant & Gender & Age & Etiology & Time of hearing loss (years) & Type of $\mathrm{Cl} /$ strategy & Time of $\mathrm{Cl}$ use (years) \\
\hline 1 & $\mathrm{M}$ & 42 & Ototoxicity & 5 & $\mathrm{C} 40 / \mathrm{CIS}$ & 12.3 \\
\hline 2 & $\mathrm{M}$ & 52 & $\mathrm{HT}$ & 4 & $\mathrm{C} 40+/ \mathrm{ClS}+$ & 5.5 \\
\hline 3 & $\mathrm{~F}$ & 47 & Ototoxicity & 22 & Nucleus 24K/ACE & 3.9 \\
\hline 4 & $\mathrm{~F}$ & 59 & $\mathrm{HT}$ & 27 & N24 Contour/ACE & 1.8 \\
\hline 5 & M & 49 & Idiopathic & 5 & C40+/ClS+ & 5.3 \\
\hline 6 & $\mathrm{~F}$ & 51 & Idiopathic & 28 & N24 Contour/ACE & 3.8 \\
\hline 7 & M & 28 & Genetic & 3 & Nucleus 24M/ACE & 2.8 \\
\hline 8 & $\mathrm{M}$ & 62 & Ototoxicity & 31 & N24 Contour/ACE & 1.4 \\
\hline 9 & $\mathrm{M}$ & 28 & Idiopathic & 1 & Nucleus 24K/ACE & 1 \\
\hline 10 & M & 50 & Idiopathic & 15 & CI22/SPEAK & 7.6 \\
\hline 11 & $\mathrm{~F}$ & 45 & Idiopathic & 24 & HiRes 90K/HiResP & 1 \\
\hline 12 & M & 46 & Idiopathic & 30 & N24 Contour/ACE & 1.6 \\
\hline 13 & M & 22 & Meningitis & 4 & Nucleus 24K/ACE & 1.5 \\
\hline 14 & M & 54 & Otosclerosis & 3 & Nucleus $24 \mathrm{~K} / \mathrm{ACE}$ & 2.7 \\
\hline 15 & $\mathrm{~F}$ & 63 & Genetic & 2 & Nucleus 24M/ACE & 12 \\
\hline 16 & $\mathrm{M}$ & 37 & Ototoxicity & 3 & Nucleus 24K/ACE & 2 \\
\hline 17 & $\mathrm{M}$ & 38 & $\mathrm{HT}$ & 0,7 & Sonata ti100/FSP & 1.4 \\
\hline 18 & $\mathrm{M}$ & 42 & Mumps & 12 & N24 Contour/ACE & 2.5 \\
\hline 19 & $\mathrm{M}$ & 24 & $\mathrm{HT}$ & 1 & Nucleus 24K/ACE & 2.7 \\
\hline Mean $\pm S D$ & NA & $44.1 \pm 9.7$ & NA & $11.6 \pm 11.4$ & NA & $3.8 \pm 3.4$ \\
\hline
\end{tabular}

Caption: $\mathrm{Cl}$ = cochlear implant; $\mathrm{M}=$ male; $\mathrm{F}=$ female; $\mathrm{HT}$ = head trauma; $\mathrm{SD}=$ standard deviation; $\mathrm{NA}=$ not applicable 
The analysis of the answers to question 1 "How often do you listen to and/or have you listened to music?" showed that of the 19 participants, $6(31.6 \%)$ mentioned listening to music frequently and $8(42.1 \%)$ referred always listening to music, when questioned about the period before HL. However, after the CI, only 4 subjects $(21.1 \%)$ always listened to music and 2 listened to it often (10.5\%). The distribution of frequencies and percentages of the other responses for this question was as follows:

- Before HL: $10.5 \%(\mathrm{n}=2)$ mentioned listening to music rarely and $15.8 \%(\mathrm{n}=3$ ) scored listening to music occasionally;

- After the CI: 3 participants (16.8\%) never listened to music, $5(26.3 \%)$ listened to music rarely, and 5 (26.3\%) did so occasionally.

In Question 2 "What role did/does music play in your life?", the results indicated that $31.6 \%(\mathrm{n}=6) \mathrm{CI}$ users considered music to be very important in the period after the CI. The other responses were divided between the options: no importance $(5.3 \%$; $n=1)$, little importance $(15.8 \% ; \mathrm{n}=3)$, medium importance $(21.1 \%$; $\mathrm{n}=4)$, and important $(26.3 \%$; $\mathrm{n}=5)$. Before HL, answers were distributed as of medium importance $(21.1 \% ; n=4)$, important $(42.1 \% ; n=8)$, and very important $(35.8 \% ; n=7)$.

The number of hours spent in activities related to listening to music before HL was similar for the response options in question 3 "When you are/were listening to music, how long did you listen?", and participants chose from 30 minutes to 1 hour until the whole day. However, after the CI, $42.1 \%(n=8)$ interviewees listened to music less than 30 minutes a day. The full results are shown in Table 2.

The reasons why CI users listened to music were different. This aspect was assessed in question 7, "Why do you listen to music?" That analysis considered the number of participants who selected each possible reason. Sixteen (84.2\%) CI users mentioned listening to music for pleasure. The other reasons were for satisfaction and to relax, both chosen by 11 individuals $(57.9 \%)$. The details obtained by the application of this question are given in Table 3. In this question, each participant could choose as many alternatives as necessary.

To answer the question "Where have you listened to or do you currently listen to music?' (question 14), CI users selected all possible locations. However, the most frequent answers were the following: on the radio in the car, on the radio at home, and on TV (Table 4).

Another aspect approached in the questionnaire was the music genre mostly appreciated by CI users, assessed by question 15. The most appreciated types of music were Brazilian popular music (MPB), country music, dance music, and religious songs (Table 5).

\section{DISCUSSION}

Music perception and appreciation are considered to be valuable measures for the population of CI users. However, in Brazil, there are no standardized instruments of subjective evaluation. Therefore, enabling an instrument to assess such aspects allows knowing the musical activities of CI users.

Table 3. Number of participants and percentage for each reason selected in question $7(n=19)$, "Why do you listen to music?"

\begin{tabular}{lcc}
\hline Reasons & $\mathrm{n}$ & $\%$ \\
\hline For pleasure & 16 & 84.2 \\
Emotional satisfaction & 11 & 57.9 \\
To relax & 11 & 57.9 \\
To improve my mood & 8 & 42.1 \\
To dance & 8 & 42.1 \\
Professional reasons & 1 & 5.3 \\
To stay awake & 0 & 0 \\
\hline
\end{tabular}

Table 4. Number of participants and percentage for each music genre selected for question 15 ( $n=19)$, "Which musical genre do you listen to?"

\begin{tabular}{lcc}
\hline Type & $\mathrm{n}$ & $\%$ \\
\hline BPM & 14 & 73.7 \\
Country music & 11 & 57.9 \\
Dance music & 10 & 52.6 \\
Religious music & 10 & 52.6 \\
Rock & 8 & 42.1 \\
Classical music & 6 & 31.6 \\
Jazz & 2 & 10.5 \\
Ópera & 1 & 5.3 \\
\hline
\end{tabular}

Caption: BPM = Brazilian popular music

Table 5. Number of participants and percentage for each location selected for question $14(\mathrm{n}=19)$, "Where do you listen to music?"

\begin{tabular}{llc}
\hline Place & $\mathrm{n}$ & $\%$ \\
\hline On the radio at home & 12 & 63.2 \\
TV & 12 & 63.2 \\
On the radio in the car & 11 & 57.9 \\
Social events & 9 & 47.4 \\
LP/CD/MC/MP3 & 8 & 42.1 \\
Religious institutions & 5 & 26.3 \\
\hline
\end{tabular}

Caption: $\mathrm{TV}=$ television; $\mathrm{LP}=$ long play; $\mathrm{CD}=$ compact disc; $\mathrm{MC}=$ microcomputers; MP3 = MPEG audio layer-3

Table 2. Distribution of frequencies and percentages of answers in question $3(n=19)$, "When you are/were listening to music, how long did you listen?"

\begin{tabular}{|c|c|c|c|c|c|c|c|c|c|c|c|c|}
\hline \multirow{2}{*}{ Occasion } & \multicolumn{2}{|c|}{$<30 \mathrm{~min}$} & \multicolumn{2}{|c|}{$30 \mathrm{~min}-1 \mathrm{~h}$} & \multicolumn{2}{|c|}{$1-2 \mathrm{~h}$} & \multicolumn{2}{|c|}{$+2 \mathrm{~h}$} & \multicolumn{2}{|c|}{ All day } & \multicolumn{2}{|c|}{ Total } \\
\hline & $\mathrm{n}$ & $\%$ & $\mathrm{n}$ & $\%$ & $\mathrm{n}$ & $\%$ & $\mathrm{n}$ & $\%$ & $\mathrm{n}$ & $\%$ & $\mathrm{n}$ & $\%$ \\
\hline Before the onset of your hearing loss & 1 & 5.3 & 5 & 26.3 & 4 & 21.1 & 5 & 26.3 & 4 & 21.1 & 19 & 100 \\
\hline Since receiving your $\mathrm{Cl}$ & 8 & 42.1 & 5 & 26.3 & 2 & 10.5 & 3 & 15.8 & 1 & 5.3 & 19 & 100 \\
\hline
\end{tabular}

Caption: $\mathrm{Cl}=$ cochlear implant 
From that perspective, the cultural adaptation of MUMU to Portuguese was essential because there are cultural and social differences that might be present in the original version created in English.

These differences are not solved by a mere literal translation. It is necessary to consider the cultural adaptation procedure and the application of the questionnaire, so that it is possible to determine the equality of metrical characteristics between the original and the translated versions ${ }^{(14)}$.

After the Questionário de Música de Munique was created, it was applied on $19 \mathrm{CI}$ users with postlingual HL, as recommended by the author of the questionnaire, because MUMU compares the activities between different periods of the implant users' lives, including before and after the $\mathrm{CI}^{(8)}$.

The results showed a decrease in the frequency with which CI users listened to music by comparing the periods before and after the CI. This reflects the difficulty of this population to maintain the musical habits they had before HL. Lassaletta et al. ${ }^{(5)}$ registered the same result by using an adaptation of the questionnaire by Gfeller et al. ${ }^{(7)}$. However, even so the role music played in the life of each participant in this study did not change - it remained important. This affects the quality of life of CI users, who stopped listening to music, but still consider it to be important.

Different factors may influence music appreciation, including technological aspects of the device and individual factors of HL, time of sensory deprivation, among others. In this study, these characteristics were not correlated to the responses obtained by the application of the questionnaire because the proposal was the description of musical activities, obtained by cultural adaptation. Further studies can assess such factors.

Even though CI users did not effectively participate in activities involving music after the CI, when they did so the reasons were for pleasure, satisfaction, and relaxation. Similar answers were scored in the study that used MUMU to assess music appreciation among unilateral and bilateral CI users ${ }^{(15)}$.

The answers obtained regarding the preferred type of music showed the influence of Brazilian culture. The authors of the questionnaire observed that the cultural questions present its value and, therefore, it is important to adapt the instrument to different languages.

The questions chosen for the analysis of responses in this group were based on the suggestions from the authors of MUMU because it is a long questionnaire composed of 25 questions ${ }^{(9,15)}$.

In further studies, the Questionário de Música de Munique will enable the comparison and the correlation between objective and subjective measures related to music among CI users. Objective measures that assess music perception by using these tests can be compared to the subjective perceptions and judgments obtained by the questionnaire.

\section{CONCLUSIONS}

This study allowed the cultural adaptation of MUMU for the Brazilian population, which was called Questionário de Música de Munique.

There was cultural equivalence between the versions of MUMU in English and in Portuguese, once CI users did not have difficulties to interpret and understand the questions and the terms used.
The study enabled to verify the applicability of the Questionário de Música de Munique in the routine of a follow-up clinic for adult CI users, thus establishing a profile of the activities connected to music in their daily lives.

\section{ACKNOWLEDGMENT}

We acknowledge the financial support (process number 2007/59972-0) provided by the Fundação de Amparo à Pesquisa do Estado de São Paulo (FAPESP) for the conduction of this study.

*NBFL was in charge of data collection and tabulation, collaborated with data analysis, and the elaboration of the manuscript; $M C B$ was responsible for the project and study design, and supervised data collection; OAC was in charge of the general orientation of the stages of execution and elaboration of the manuscript.

\section{REFERENCES}

1. Pankseep J. The emotional sources of 'Chills' induced by music. Music Percept. 1995;13(2):171-207.

2. Gfeller K, Turner C, Mehr M, Woodworth G, Fearn R, Knutson JF, et al. Recognition of familiar melodies by adult cochlear implant recipients and normal-hearing adults. Cochlear Implants Int. 2002;3(1):29-53.

3. Stainsby TH, McDermott HJ, McKay CM, Clark GM. Preliminary results on spectral shape perception and discrimination of musical sounds by normal hearing subjects and cochlear implantees. In: Proceedings International Computer Music Conference; 1997 Sep 25-30; Hellas. Hellas: ICMC; 1997.

4. Mirza S, Douglas SA, Lindsey P, Hildreth T, Hawthorne M. Appreciation of music in adult patients with cochlear implants: a patient questionnaire. Cochlear Implants Int. 2003;4(2):85-95.

5. Lassaletta L, Castro A, Bastarrica M, Pérez-Mora R, Madero R, de Sarriá J, et al. Does music perception have an impact on quality of life following cochlear implantation? Acta Otolaryngol. 2007;127(7):682-6.

6. McDermott HJ. Music perception with cochlear implants: a review. Trends Amplif. 2004;8(2):49-82.

7. Gfeller K, Christ A, Knutson JF, Witt S, Murray KT, Tyler RS. Musical backgrounds, listening habits, and aesthetic enjoyment of adult cochlear implant recipients. J Am Acad Audiol. 2000;11(7):390-406.

8. Brockmeier SJ, Nopp P, Vischer M, Baumgartner W, Stark T, Schoen F, et al. Correlation of speech and music perception in postlingually deaf Combi 40/40+ users. In: Kubo T, Takahashi Y, Iwaki T, editors. Cochlear implants: an update. The Hague: Kugler Publications; 2002. p. 459-64.

9. Brockmeier SJ, Grasmeder M, Passow S, Mawmann D, Vischer M, Jappel A, et al. Comparison of musical activities of cochlear implant users with different speech-coding strategies. Ear Hear. 2007;28(2 Suppl):49S-51S.

10. Leal MC, Shin YJ, Laborde ML, Calmels MN, Verges S, Lugardon $\mathrm{S}$, et al. Music perception in adult cochlear implant recipients. Acta Otolaryngol. 2003;123(7):826-35.

11. Giusti E, Befi-Lopes DM. Tradução e adaptação transcultural de instrumentos estrangeiros para o Português Brasileiro (PB). Pró-Fono R Atual Cient. 2008;20(3):207-10.

12. Stark T, Brockmeier SJ, Nopp P, Vischer M, Baumgartner WD, Schön F, et al. Correlation of speech and music appreciation in post-lingually deaf Combi 40/40+ cochlear implant users. Cochlear Implants Int. 2003;4(Suppl 1):68-9.

13. Wang S, Dong R, Zhou Y, Li J, Qi B, Liu B. Emotional response to music by postlingually-deafened adult cochlear implant users. Lin Chung Er Bi Yan Hou Tou Jing Wai Ke Za Zhi. 2012;26(19):879-81. Chinese

14. Guillemin F, Bombardier C, Beaton D. Cross-cultural adaptation of health-related quality of life measures: literature review and proposed guidelines. J Clin Epidemiol. 1993;46(12):1417-32.

15. Veekmans K, Ressel L, Mueller J, Vischer M, Brockmeier SJ. Comparison of music perception in bilateral and unilateral cochlear implant users and normal-hearing subjects. Audiol Neurootol. 2009;14(5):315-26. 
Appendix 1. Questionário de Música de Munique

Nome:

Data $(\mathrm{dd} / \mathrm{mm} / \mathrm{aa})$ :

Data de nascimento ( $\mathrm{dd} / \mathrm{mm} / \mathrm{aa})$ :

Por favor, assinale todos os dispositivos que você utiliza:

$\square$ Implante coclear direito $\quad \square$ Implante coclear esquerdo

$\square$ Aparelho auditivo direito $\square$ Aparelho auditivo esquerdo

$\square$ Implante coclear/DUET direito $\square$ Implante coclear/DUET esquerdo

1. Com que frequência você ouve e/ou ouvia música?

Por favor, assinale a resposta que mais se aplica.

Com que frequência você ouvia música antes de perder a audição?

Frequentemente $\quad 10987654321$ Nunca

Com que frequência você ouvia música após a perda auditiva e antes de receber o implante coclear (IC)?

Frequentemente $\quad 10987654321 \quad$ Nunca

Com que frequência você ouve música atualmente, após receber o implante coclear?

Frequentemente $\quad 10987654321 \quad$ Nunca

2. Que papel a música desempenhou/desempenha em sua vida?

Por favor, assinale a resposta que mais se aplica.

Antes do início da sua perda auditiva?

Muito importante $10987654321 \quad$ Nenhum

Após a sua perda auditiva, antes de receber o implante coclear?

Muito importante $10987654321 \quad$ Nenhum

Atualmente, desde que recebeu o implante coclear?

Muito importante $\quad 10987654321 \quad$ Nenhum

\begin{tabular}{ll}
\hline \hline 3. Quando você ouve/ouvia música, durante quanto tempo o faz/ \\
fazia?
\end{tabular}

4. Como a música geralmente lhe soa aos ouvidos quando você usa o implante coclear? Por favor, assinale a resposta que mais se aplica.

\begin{tabular}{lll}
\hline Natural & 10987654321 & Artificial \\
Agradável & 10987654321 & Desagradável \\
Menos reverberante & 10987654321 & Mais reverberante \\
\hline
\end{tabular}

4. Como a música geralmente lhe soa aos ouvidos quando você usa o implante coclear? Por favor, assinale a resposta que mais se aplica.

\begin{tabular}{lll}
\hline Nítida & 10987654321 & Indistinguível \\
Menos metálica & 10987654321 & Mais metálica \\
Menos reverberante & 10987654321 & Mais reverberante \\
\hline
\end{tabular}

5 . Normalmente, você liga a música diretamente no processador de fala? (por exemplo, usando a entrada que conecta dispositivos de áudio, tais como MP3)

\begin{tabular}{l}
$\square$ Sim \\
\hline 6. Como você ouve música? \\
$\square$ Como música de fundo \\
$\square$ Como meu único foco de atenção/sem distrações \\
$\square$ Ambos
\end{tabular}

7. Por que você ouve música?

Por favor, assinale todas as respostas que se apliquem.

\begin{tabular}{|c|c|c|}
\hline$\square$ Por prazer & $\begin{array}{l}\square \text { Por motivos } \\
\text { profissionais }\end{array}$ & $\square$ Satisfação emocional \\
\hline $\begin{array}{l}\square \text { Melhorar o } \\
\text { humor }\end{array}$ & $\begin{array}{r}\text { Para ficar } \\
\text { acordado }\end{array}$ & $\square$ Para dançar \\
\hline
\end{tabular}

8. Caso você ouça música com seu implante coclear, quando começou a ouvir música regularmente após receber o implante?

\begin{tabular}{|c|c|c|}
\hline $\begin{array}{l}\text { Logo após o } \\
\text { primeiro ajuste } \\
\text { (ativação) }\end{array}$ & $\square$ Após 1 semana & $\square$ Após 1 mês \\
\hline$\square$ Após 3 meses & $\square$ Após 6 meses & $\square$ Após 1 ano \\
\hline$\square$ Após 2 anos & $\square$ Mais tarde & \\
\hline
\end{tabular}

\begin{tabular}{ll}
\hline 9. Você prefere ouvir solos de instrumentos ou orquestras/bandas? \\
$\begin{array}{l}\square \text { Solo de } \\
\text { instrumento }\end{array}$ Orquestra/banda & $\begin{array}{r}\text { Não tenho } \\
\text { preferência }\end{array}$ \\
\hline
\end{tabular}

10. Caso você ouça música, quais elementos da música você consegue ouvir?

\begin{tabular}{|c|c|c|c|c|c|}
\hline \multicolumn{2}{|c|}{$\begin{array}{l}\text { Tons agradáveis, } \\
\text { mas não melodia }\end{array}$} & $\square \mathrm{Si}$ & & $\square$ Não & \\
\hline \multicolumn{2}{|l|}{ Ritmo } & $\square \mathrm{Si}$ & & $\square$ Não & \\
\hline \multicolumn{2}{|c|}{$\begin{array}{l}\text { Apenas sons } \\
\text { desagradáveis }\end{array}$} & $\square \mathrm{Si}$ & & $\square$ Não & \\
\hline \multicolumn{2}{|l|}{ Melodia } & $\square \mathrm{Si}$ & & $\square$ Não & \\
\hline \multicolumn{6}{|c|}{ 11. Você consegue distinguir as notas agudas das notas graves? } \\
\hline \multicolumn{2}{|l|}{$\square \operatorname{Sim}$} & & $\square$ Nã & & \\
\hline \multicolumn{6}{|c|}{ 12. Qual(is) instrumento(s) você consegue identificar bem? } \\
\hline \multicolumn{6}{|c|}{ Por favor, assinale todas as respostas que se apliquem. } \\
\hline$\square$ Violino & \multicolumn{2}{|c|}{$\square$ Flauta } & $\square$ Trompete & $\square$ Tuba & $\square$ Piano \\
\hline$\square$ Trompa & \multicolumn{2}{|c|}{$\square$ Violoncelo } & $\square$ Xilofone & $\square$ Trombone & $\square$ Sanfona \\
\hline$\square$ Harpa & \multicolumn{2}{|c|}{$\square$ Bateria } & $\square$ Violão & $\square$ Saxofone & \\
\hline \multicolumn{6}{|c|}{$\square$ Outro instrumento de corda } \\
\hline \multicolumn{6}{|c|}{$\square$ Outro instrumento de teclado } \\
\hline \multicolumn{6}{|c|}{$\square$ Outro instrumento de sopro } \\
\hline \multicolumn{6}{|c|}{$\square$ Algum outro instrumento que não foi mencionado } \\
\hline
\end{tabular}


Appendix 1. Continuation

\begin{tabular}{l}
\hline 13. Qual(is) instrumento(s) que você gosta de ouvir? \\
\hline$\square$ Violino $\quad \square$ Flauta $\quad \square$ Trompete $\quad \square$ Tuba $\quad \square$ Piano \\
$\square$ Trompa $\quad \square$ Violoncelo $\square$ Xilofone $\quad \square$ Trombone $\square$ Sanfona \\
$\square$ Harpa $\quad \square$ Bateria $\quad \square$ Violão $\quad \square$ Saxofone \\
$\square$ Outro instrumento de corda \\
$\square$ Outro instrumento de teclado \\
$\square$ Outro instrumento de sopro \\
$\square$ Algum outro instrumento que não foi mencionado
\end{tabular}

14. Onde você já ouviu música ou onde você ouve música atualmente?

Por favor, assinale todas as respostas que se apliquem.

Antes do início da perda auditiva

$\begin{array}{ll}\square \text { No rádio, em casa } & \square \text { No rádio do carro } \quad \square \text { Em eventos sociais } \\ \square \text { Na televisão } & \square \text { LP/CD/MC/MP3 } \begin{array}{l}\text { Em instituições } \\ \text { religiosas }\end{array}\end{array}$

Após a perda auditiva, antes de receber o implante coclear

$\square$ No rádio, em casa $\square$ No rádio do carro $\square$ Em eventos sociais

$\checkmark$ Na televisão $\quad \square$ LP/CD/MC/MP3 $\square$ Em instituições

Atualmente, desde que recebeu seu implante coclear

\begin{tabular}{ll}
$\square$ No rádio, em casa & $\square$ No rádio do carro \\
$\square$ Na televisão & $\square$ EP/CD/MC/MP3 eventos sociais \\
& $\begin{array}{l}\text { Em instituições } \\
\text { religiosas }\end{array}$ \\
\hline
\end{tabular}

15. Que tipo de música você ouve? Por favor, assinale todas as respostas que se apliquem.

\begin{tabular}{|c|c|c|c|}
\hline \multicolumn{4}{|c|}{ Antes do início da perda auditiva } \\
\hline$\square$ Clássica & $\begin{array}{l}\square \text { Ópera/ } \\
\text { opereta }\end{array}$ & $\square$ Religiosa & $\begin{array}{l}\text { Sertaneja/ } \\
\text { country }\end{array}$ \\
\hline$\square$ MPB & $\square$ Rock & $\square$ Jazz/blues & $\begin{array}{l}\square \text { Música para } \\
\text { dançar }\end{array}$ \\
\hline \multicolumn{4}{|c|}{ Após a perda auditiva, antes de receber o implante coclear } \\
\hline$\square$ Clássica & $\begin{array}{l}\square \text { Ópera/ } \\
\text { opereta }\end{array}$ & $\square$ Religiosa & $\begin{array}{l}\text { Sertaneja/ } \\
\text { country }\end{array}$ \\
\hline$\square$ MPB & $\square$ Rock & $\square$ Jazz/blues & $\begin{array}{l}\square \text { Música para } \\
\text { dançar }\end{array}$ \\
\hline \multicolumn{4}{|c|}{ Atualmente, desde que recebeu seu implante coclear } \\
\hline$\square$ Clássica & $\begin{array}{l}\square \text { Ópera/ } \\
\text { opereta }\end{array}$ & $\square$ Religiosa & $\begin{array}{l}\square \text { Sertaneja/ } \\
\text { country }\end{array}$ \\
\hline$\square$ MPB & $\square$ Rock & $\square$ Jazz/blues & $\begin{array}{l}\square \text { Música para } \\
\text { dançar }\end{array}$ \\
\hline
\end{tabular}

16. Como você classifica seu prazer em ouvir música agora?

Por favor, assinale a resposta mais adequada.

Música clássica
Muito prazer
$10987654321 \quad$ Nenhum prazer

Ópera/opereta

Muito prazer

$10987654321 \quad$ Nenhum prazer

Música religiosa

Muito prazer $\quad 10987654321 \quad$ Nenhum prazer

Música sertaneja/country

$\begin{array}{lrl}\text { Muito prazer } & 10987654321 & \text { Nenhum prazer } \\ \text { MPB } & & \\ \text { Muito prazer } & 10987654321 & \text { Nenhum prazer } \\ \text { Muito prazer } & 10987654321 & \text { Nenhum prazer }\end{array}$

\begin{tabular}{lcl}
\hline 16. Como você classifica seu prazer em ouvir música agora? \\
\hline $\begin{array}{l}\text { Rock } \\
\text { Muito prazer }\end{array}$ & 10987654321 & Nenhum prazer \\
Jazz/blues & 10987654321 & Nenhum prazer \\
Muito prazer & 109 & \\
Música para dançar & & \\
Muito prazer & 10987654321 & Nenhum prazer \\
\hline
\end{tabular}

17. Você toca/tocava/já tocou algum instrumento?

Por favor, assinale a resposta mais adequada.

Quando criança?

Frequentemente $\quad 10987654321 \quad$ Nunca

Antes do início da perda auditiva?

Frequentemente $\quad 10987654321 \quad$ Nunca

Após a perda auditiva, antes de receber o implante coclear?

Frequentemente $\quad 10987654321 \quad$ Nunca

Atualmente, desde que recebeu o implante coclear?

Frequentemente $\quad 10987654321 \quad$ Nunca

Caso você não toque ou nunca tenha tocado um instrumento, pule a pergunta 18 e vá para a pergunta 19 !

18. Qual(is) instrumento(s) você já tocou ou toca atualmente?

Por favor, assinale todas as respostas que se apliquem.

Quando criança:

$\begin{array}{llll}\square \text { Flauta doce } & \square \text { Flauta } & \square \text { Metais } & \square \text { Clarinete } \\ \square \text { Piano } & \square \text { Teclado } & \square \text { Sanfona } & \square \text { Violão } \\ \square \text { Violino } & \square \text { Percussão } & \square \text { Saxofone } & \end{array}$

$\square$ Outro instrumento de corda

$\square$ Outro instrumento de teclado

Outro instrumento de sopro

$\square$ Algum outro instrumento que não foi mencionado

Antes do início da perda auditiva:

$\begin{array}{llll}\square \text { Flauta doce } & \square \text { Flauta } & \square \text { Metais } & \square \text { Clarinete } \\ \square \text { Piano } & \square \text { Teclado } & \square \text { Sanfona } & \square \text { Violão } \\ \square \text { Violino } & \square \text { Percussão } & \square \text { Saxofone } & \end{array}$

$\square$ Outro instrumento de corda

$\checkmark$ Outro instrumento de teclado

Outro instrumento de sopro

Algum outro instrumento que não foi mencionado

Após a perda auditiva, antes de receber o implante coclear:

$\begin{array}{llll}\square \text { Flauta doce } & \square \text { Flauta } & \square \text { Metais } & \square \text { Clarinete } \\ \square \text { Piano } & \square \text { Teclado } & \square \text { Sanfona } & \square \text { Violão } \\ \square \text { Violino } & \square \text { Percussão } & \square \text { Saxofone } & \end{array}$

$\checkmark$ Outro instrumento de corda

$\checkmark$ Outro instrumento de teclado

Outro instrumento de sopro

Algum outro instrumento que não foi mencionado

Atualmente, desde que recebeu o implante coclear:

$\begin{array}{ll}\square \text { Flauta doce } \quad \square \text { Flauta } & \square \text { Metais } \\ \square \text { Piano } \quad \square \text { Teclado } \quad \square \text { Sanfona } \quad \square \text { Violão } \\ \square \text { Violino } \quad \square \text { Percussão } \quad \square \text { Saxofone } \\ \square \text { Outro instrumento de corda } \\ \square \text { Outro instrumento de teclado } \\ \square \text { Outro instrumento de sopro } \\ \square \text { Algum outro instrumento que não foi mencionado }\end{array}$

Continues.. 
Appendix 1. Continuation

19. Você canta ou já cantou? Assinale a resposta adequada.

Antes do início da perda auditiva?

Frequentemente $\quad 10987654321 \quad$ Nunca

Após a perda auditiva, antes de receber o implante coclear?

Frequentemente $\quad 10987654321 \quad$ Nunca

Atualmente, desde que recebeu o implante coclear?

Frequentemente $\quad 10987654321 \quad$ Nunca

Caso você não cante/nunca tenha cantado, pule as perguntas 20 e 21 e vá diretamente para a pergunta 22!

20. Caso você cante/já tenha cantado, informe onde canta/cantava.

Assinale todas as respostas que se apliquem.

Antes do início da perda auditiva

\begin{tabular}{|c|c|c|}
\hline$\square$ Em um coral & $\square$ Em um grupo & $\square$ Em casa, sozinho \\
\hline No carro & $\begin{array}{l}\square \text { Em instituições } \\
\text { religiosas }\end{array}$ & $\square$ Cor \\
\hline
\end{tabular}

Após a perda auditiva, antes de receber o implante coclear

$\begin{array}{lll}\square \text { Em um coral } & \square \text { Em um grupo } & \square \text { Em casa, sozinho } \\ \square \text { No carro } & \square \text { Em instituições } & \square \text { Com amigos }\end{array}$

Atualmente, desde que recebeu o implante coclear

\begin{tabular}{lll}
$\square$ Em um coral & $\square$ Em um grupo & $\square$ Em casa, sozinho \\
$\square$ No carro & $\square \begin{array}{l}\text { Em instituições } \\
\text { religiosas }\end{array}$ & $\square$ Com amigos \\
\hline
\end{tabular}

21. Caso você cante/já tenha cantado, informe o que canta/cantava. Por favor, assinale todas as respostas que se apliquem.

Antes do início da perda auditiva

\begin{tabular}{|c|c|c|c|}
\hline $\begin{array}{l}\square \text { Música } \\
\text { sertaneja }\end{array}$ & $\begin{array}{l}\square \text { Música } \\
\text { clássica }\end{array}$ & $\begin{array}{c}\square \text { Canções } \\
\text { de Natal }\end{array}$ & $\square$ Jazz/blues \\
\hline $\begin{array}{l}\text { Música } \\
\text { religiosa }\end{array}$ & $\begin{array}{l}\square \text { Ópera/ } \\
\text { opereta }\end{array}$ & $\square \mathrm{MPB} /$ rock & \\
\hline
\end{tabular}

Após a perda auditiva, antes de receber o implante coclear

$\begin{array}{ll}\text { Música } & \square \text { Ópera/ } \\ \text { religiosa } & \text { opereta }\end{array}$ MPB/rock

\begin{tabular}{|c|c|c|c|}
\hline \multicolumn{4}{|c|}{ 21. Caso você cante/já tenha cantado, informe o que canta/cantava. } \\
\hline $\begin{array}{l}\text { Música } \\
\text { sertaneja }\end{array}$ & $\begin{array}{l}\square \text { Música } \\
\text { clássica }\end{array}$ & $\begin{array}{l}\square \text { Canções } \\
\text { de Natal }\end{array}$ & \multirow[t]{2}{*}{$\square$ Jazz/blues } \\
\hline $\begin{array}{l}\text { Música } \\
\text { religiosa }\end{array}$ & $\begin{array}{l}\square \text { Ópera/ } \\
\text { opereta }\end{array}$ & $\square \mathrm{MPB} /$ rock & \\
\hline \multicolumn{4}{|c|}{ Atualmente, desde que recebeu o implante coclear } \\
\hline $\begin{array}{l}\square \text { Música } \\
\text { sertaneja }\end{array}$ & $\begin{array}{l}\square \text { Música } \\
\text { clássica }\end{array}$ & $\begin{array}{l}\square \text { Canções } \\
\text { de Natal }\end{array}$ & \multirow[t]{2}{*}{$\square$ Jazz/blues } \\
\hline $\begin{array}{l}\text { Música } \\
\text { religiosa }\end{array}$ & $\begin{array}{l}\square \text { Ópera/ } \\
\text { opereta }\end{array}$ & $\square \mathrm{MPB} / \mathrm{rock}$ & \\
\hline
\end{tabular}

22. Você teve aulas de música fora da escola (aula de instrumento e/ou canto)?

$\square$ Sim $\square$ Não

Caso não tenha recebido aula de música, pule a pergunta 23 e vá para a pergunta 24 !

\begin{tabular}{l} 
23. Quanto tempo você fez aula de música fora da escola (aula de \\
instrumento e/ou canto)? \\
\hline$\square$ Menos de 3 anos \\
\hline 24. Você já ouviu música após receber o implante coclear? \\
\hline$\square$ Sim \\
Caso não tenha ouvido música após receber o implante, pule a \\
pergunta 25 ! \\
\hline 25. Em que circunstâncias você ouviu música após receber o \\
implante coclear? \\
\hline Assinale todas as respostas que se apliquem. \\
$\square$ Ouvi músicas conhecidas repetidamente \\
$\square$ Li e toquei música \\
$\square$ Ouvi músicas desconhecidas repetidamente \\
$\square$ Toquei músicas conhecidas repetidamente sem ler a música em \\
questão \\
$\square$ Ouvi e li música \\
$\square$ Treinei ouvir música durante a minha recuperação \\
$\square$ Tive aulas de música
\end{tabular}

Agradecemos sua contribuição! 